1 Bordering on neglect: 'environmental justice' in Australian planning

2

3

4 Jason Byrne $^{1^{*}}$ and Diana MacCallum ${ }^{2}$

5

6

7

8

9

10 1. * Correspondence Author: Senior Lecturer, School of Environment, Environmental

11 Futures Centre, Building G31, Room 3.06, Griffith University, Gold Coast campus, QLD

12 4222, Australia. Phone: +61 75552 7723, Fax: +61 75552 8244, Email:

13 jason.byrne@griffith.edu.au.

14 2. Diana MacCallum, Lecturer, School of Built Environment, Curtin University, GPO Box

15 U1987, Perth 6845, Australia, +61 89266 7313, Email: diana.maccallum@curtin.edu.au

16

17 
Bordering on neglect: 'environmental justice’ in Australian planning

23 Abstract

24 Australian environmental justice research is limited, with scant planning literature on this topic. The Planning Institute of Australia's core business omits environmental justice concerns. State and local governments are silent on the matter. Few Australian planners would recognise the term. Yet the basic ideals behind environmental justice underpin the core principles of accessibility, equity, social inclusion, and participatory democracy which, in principle, inform Australian planning policies and practice. In this paper we begin the important task of crossing the borders of ignorance to engage with environmental justice in Australian planning. We review the US origins of the concept, discuss the processes behind the formation of unjust environmental landscapes (built and organic), and overview some contemporary Australian environmental justice issues warranting closer scrutiny. We conclude by charting a research agenda and pointing to changes for planning practice. In so doing, we seek to bridge borders across history, places, disciplines, scholarship and practice.

Keywords: environmental justice, land use planning, Australia, equity, urban development 
Bordering on neglect: 'environmental justice’ in Australian planning

Introduction

Australian planners have wrongly assumed they can protect urban residents from pollution by designating some areas as sacrifice zones for noxious and polluting land uses (Troy, 2000, p. 142). The problem with such reductionist thinking (Haughton, 1999) is that marginalised and vulnerable groups are typically relegated to places with low environmental quality (Forster, 2004; Gleeson and Randolph, 2002). These places may exhibit chronic air, water, noise, heat and light pollution, substandard housing, higher crime rates, more liquor stores, poor quality or absent fruit and vegetable markets and green-spaces, and can be flood-prone (James, 2009; Laidlaw and Taylor, 2011; Giles-Corti et al., 2003). In Australia, such places are frequently home to Indigenous people, migrants, working poor, homeless, welfare-dependent and other vulnerable populations, partly because they cannot live elsewhere (Arcioni and Mitchell, 2005; Lloyd-Smith and Bell, 2003). This inequitable concentration of vulnerable people in hazardous places is called environmental injustice (Low and Gleeson, 1998).

In the United States of America (US), activists have spent three decades combating environmental inequalities and promoting 'environmental justice'. This social movement has been less influential in Australia. Australia lacks easily identifiable environmental justice organisations and Australian planning has virtually ignored environmental injustice problems (see Fincher and Iveson, 2012), partly because environmental health typically falls outside the jurisdiction of planning (Lloyd-Smith and Bell, 2003). Australian land use planning schemes lack environmental justice provisions; national and state environmental legislation is similarly silent. State and local government planning departments have no environmental 
justice bureaus. Few Australian universities teach their planning students about environmental justice; awareness of the issue is not required for the accreditation of planning degrees. Nonetheless, environmental injustices exist in Australia, injustices which spatially reproduce and express inequality between socio-economic and socio-demographic groups. Planning is often complicit in processes that create environmentally unjust outcomes. Australian planning's failure to engage with environmental justice warrants attention. In this paper we seek to better understand why Australian planning seemingly neglects environmental justice concerns. We begin by explaining the concept of environmental justice and briefly reviewing its US history, establishing Australian relevance. We then consider planning's role in environmental justice issues internationally, discussing socio-political processes that create environmental injustices, and giving Australian examples. We examine Australian historical and contemporary environmental justice problems, and how Australian planners have engaged with them. We conclude by identifying opportunities for research and action. Limited space means we can only begin this conversation.

\section{What is environmental (in)justice?}

Built and organic environments are highly differentiated between places, across scales, and across time (Harvey, 1996). Environmental injustice refers to the inequitable spatial distribution of environmental harms and benefits (Low and Gleeson, 1998) arising from land and property development, unjust planning processes, uneven law enforcement, and limited public participation in decision-making. Environmental justice specifically refers to the concept that: "everyone has the right to inhabit clean, healthy and safe environments, and to enjoy equal access to safe and healthy workplaces, schools, recreation areas and nutritious 
food, irrespective of race, ethnicity, gender, class, disability and other 'axes of difference’” (Byrne, 2010). It is sometimes called ‘social justice environmentalism’ (Rose-Johnson, 1994) and is allied with the idea of 'just sustainabilities' (Agyeman et al., 2003).

Arising from the US Civil Rights Movement, environmental justice first grew to prominence in the 1980s (Bullard, 1990). The movement began at the neighbourhood and community scale when groups of African-Americans, Native Americans, Latinos and other 'people of colour' protested the disproportionate concentration of unwanted land uses around their homes, workplaces, schools, shopping places and recreation areas (Bullard, 1993).

These land uses included: polluting factories, landfill sites, waste incinerators, medical waste, sewage treatment plants, toxic waste dumps, power stations, and cement batching plants (Bullard, 1996). Rural areas exhibited other environmental problems, such as pesticide and herbicide contamination, which disproportionately impacted migrant and non-White farmlabourers (Arcury et al., 2002; Perfecto, 1993). Affected people joined together with church leaders and politicians of colour to form a powerful social movement which initiated investigations into the spatial concentration of harmful land uses within non-White communities, and began to catalogue instances of environmental discrimination (Bryant and Bryant, 1995).

Studies by government and religious organisations such as the United States General Accounting Office (1983) and the United Church (1987) found that so-called 'minority' communities were unequally burdened by environmental harm. These investigations catalysed a vast research effort. The co-location of people of colour and environmental harm became known as environmental racism (Pulido, 1996). Activists recognised that sociospatial environmental injustices stemmed from what US geographer Laura Pulido (2000) termed 'White privilege'. Pulido argued that Whites can use their privileged social status (gained through ethno-racial systems of oppression) to secure better incomes, better 
education, and political power, enabling them to occupy the highest quality environments (e.g. near the ocean, on hilltops, next to forests and parks) and thus escape pollution, heat and oftentimes natural hazards (Pulido et al., 1996). In turn, many people of colour (non-Whites) have been relegated to contaminated, hot, polluted and dangerous environments. Forster (2004, p. 120) has noted similar patterns in Australia. disproportionately concentrated in places where poor people live (Holifield, 2001). Often race and class are intertwined. In recent decades though, the environmental justice agenda has expanded to embrace a broader definition of marginality and vulnerability, beyond race, ethnicity and class, to include age, gender, disability, health-status and other axes of difference (see Powell and Stewart, 2001; Walker, 2009).

Environmental injustice claims and environmental justice research have not escaped criticism (Kevin, 1997). Early critiques focused on methods used to prove that co-location of environmental harm and vulnerable people were more than coincidence (Boer et al., 1997). Later criticism focused on the scale chosen for environmental justice research, suggesting that injustice was an artefact of the unit of analysis (e.g. neighbourhoods, postcodes, census collection districts or regions) (Cutter et al., 1996; Williams, 1999). However, researchers and activists quickly demonstrated through improved methodologies across varying scales that the co-location of vulnerable people and harmful places was real. A growing body of US revealing that different but interrelated processes can produce environmentally unjust landscapes (Richardson et al., 2010). 


\section{Mechanisms of environmentally injustice}

140 Environmental justice research in the US and Europe has identified that injustices are produced through various mechanisms (Wilson et al., 2008). These mechanisms include: intentional targeting, market factors, differential law enforcement, biased decision-making, and limited opportunities for public participation (Byrne, 2010). Different conceptions of

144 justice are involved here - intentional targeting and market mechanisms invoke ideas of distributive justice; differential law enforcement and biased decision-making raise issues of procedural justice; and a lack of public participation suggests that participatory justice is absent (Low, 2000).

\section{Intentional targeting}

Planning has been implicitly and often explicitly involved in the siting of unwanted land uses

151 (National Academy of Public Administration, 2003). Researchers have found examples where planners, policy makers, developers and public officials have collaborated to locate unwanted and toxic facilities in neighbourhoods occupied by disproportionately higher numbers of marginalised and vulnerable people. In one example well known to planning scholarship, a grassroots group called the Mothers of East Los Angeles (MELA) successfully resisted an attempt to site a waste incinerator in their community (see Sandercock, 1998). Document searches revealed that their neighbourhood was targeted for this facility because it was thought residents would offer lower resistance than political powerful, White communities (Bullard, 1999; Schlosberg, 1999). makers and decision makers intentionally disregard marginalised and vulnerable communities. In Los Angeles, a transit-racism case was brought before the courts and 
succeeded, when the Bus Riders Union successfully demonstrated that the Metropolitan Transportation Authority had allocated its oldest and most polluting buses to poor and coloured inner-city neighbourhoods, whereas new cleaner buses and new light-rail infrastructure were provided to wealthier, White, suburban communities (Burgos and Pulido, 1998; Martin, 2005). In Australia, limited service provision and substandard infrastructure in remote Aboriginal and Torres Strait Islander settlements is an example of malign neglect (Green at al., 2012).

\section{Market mechanisms}

Many environmental justice studies have sought to document 'which came first' - the polluting facilities or the vulnerable people (Been, 1994). A 'market effect' appears to operate in some cases. For example, property values are lower around unwanted land uses, such as mining and smelting activities in Mount Isa, Queensland (Neelawala et al., 2012). Marginalised and vulnerable people, who are attracted by more affordable housing in these locales, can become spatially concentrated near polluting facilities and contaminated sites (Pastor Jr. et al., 2001; Richardson et al., 2010). Market mechanisms can also operate to 'price people out' of neighbourhoods when unwanted land uses or environmental contaminants are removed, either by natural attrition or through planning intervention, as in the case of urban redevelopment projects (Gamper-Rabindran and Timmins, 2011).

As an instrument of capitalist governance, planning is complicit in many of the political-economic processes that cause environmental injustices (Wilson et al., 2008; Arcioni and Mitchell, 2005). For instance, urban renewal projects may ‘clean up’ degraded, urban land to facilitate redevelopment for high-end apartments, housing, shopping and entertainment. Seldom is attention given to the consequences of displacing populations who 
once occupied these spaces (Searle and Byrne, 2002). In their study of the impact of the East Perth Redevelopment Project in Perth for example, Byrne and Houston (2005) found that Aboriginal people, migrants and low-income earners were displaced as redevelopment occurred - even though they bore the burden of decades of pollution. Some may argue that planners have limited capacity to strongly intervene in property markets (Gleeson and Coiacetto, 2007) and thus cannot be held responsible for injustices arising from property markets. Yet the spatial concentration of vulnerable people in hazardous places is inequitable. Surely planners have a duty of care to prevent such harm.

\section{Differential law enforcement}

197 Environmental justice problems can also occur when planning laws are not applied uniformly. Researchers have shown that planning and environmental agencies may take longer to respond to nuisance complaints in poor and coloured neighbourhoods compared to wealthier, White, and politically powerful neighbourhoods (Bryant and Bryant, 1995; Bullard and Johnson, 2000; Shapiro, 2005). It is also more difficult for marginalised and vulnerable people to pursue legal action because they may: lack the financial wherewithal; be politically marginalised; or fear retribution if they raise a complaint (Bullard, 1993, 1996).

Consequently, some companies can evade environmental regulation in vulnerable communities, which they cannot do elsewhere (Mennis, 2005).

Cumulative airborne particulate levels in the Hunter Valley can significantly exceed health standards, despite individual mine-sites complying with regulated air quality. Higginbotham et al., (2010, p. 260) suggest that authorities have done little to remedy this situation because 
many communities in the Hunter Valley are comparatively disadvantaged 'in terms of income, education, access to services and lack of electoral power’.

\section{Biased decision-making}

Callewaert (2002) has argued that environmental justice is a "socio-historical process.” In the United States, housing discrimination practices (e.g. racially restrictive covenants) and the failure of permitting agencies to monitor the compliance history of facilities and their cumulative pollution impacts, has disproportionately impacted people of colour (Callewaert, 2002). In a similar fashion, Pulido, et al. (1996) argue that deep-rooted patterns of sociospatial exclusion have underpinned historical town-planning in Los Angeles. They found neighbourhoods zoned exclusively for residential purposes were located near the ocean and in hilly areas (above air pollution) and were occupied primarily by wealthier Whites. Places zoned for industries and polluting land uses were located inland, alongside neighbourhoods occupied predominantly by Latinos and African-Americans.

As we shall show in our historical review of environmental justice in Australia, similar patterns of decision-making may have shaped places such as Kwinana in Western Australia and Elizabeth in South Australia. During the 1960s, public housing agencies constructed housing in close proximity to newly developed outer metropolitan heavy industrial estates - spatially concentrating working class people in areas of higher pollution, many of whom were southern European migrants (Forster, 2004; Randolph, 2004).

\section{Limited public participation}

Power relations and decision-making processes within lending institutions, corporations, and enforcement agencies can favour the interests of elites over others, leading to 
environmentally unjust outcomes. The interests of marginalised communities can be subordinated to those of powerful corporations and landholders, not only through choice, bias and markets - as noted above, but because the voices of the vulnerable are simply not heard. Kurtz (2007) for example, considered citizen participation in planning decision-making processes in New Orleans. She found inadequate public involvement excluded marginalised and vulnerable communities, contributing directly to the concentration of vulnerable people in hazardous places - not just in flood-prone areas and in poor quality housing, but also alongside polluting factories and waste storage areas (also see Fielding and Burningham, 2005; Maantay and Maroko, 2009). Even in cases where 'public' participation is actively sought (an acknowledged trend of the last few decades), most common planning strategies for doing this appear to heavily favour those with good financial resources, knowledge, and political networks, that is, wealthier educated classes (Rydin and Pennington, 2000). planning education ill-equip planners for managing effective Aboriginal and Torres Strait Islander participation in environmental planning and natural resource management. Through detailed case studies of planning in Mapoon, Queensland and in the Queensland wet tropics, these two scholars show how Indigenous involvement in planning has been either cursory and transitory, or worse still insensitive, ignorant, and ultimately exclusionary. Tan et al. (2012) argue that similar problems plague planning for coal seam gas extraction in Condamine, Queensland. They argue that public involvement in decision-making about mining impacts is negligible, despite potentially environmentally unjust outcomes for rural communities. 
257 As we noted at the beginning of this paper, comparatively little has been written about environmental justice in Australia. Nevertheless, an examination of Australian literature about historical patterns of pollution and immigration suggests that mechanisms similar to those described above also appear to have shaped environmental inequality in Australian cities.

From the nineteenth century until the mid-twentieth century, industries tended to be located in inner city areas in Australia, clustering around rail transportation and ports (Logan, 1966). Housing was more affordable closer to industrial areas, but of lower quality (Lewis and MacLeod, 1987). In Australia, inner city and suburban industrial areas at this time were contaminated with a range of environmental pollutants - some of which could readily be dispersed to surrounding residential areas, and which we now know are associated with increased morbidity and mortality (Simpson et al., 2007; Wang et al., 2009).

Working-class residential areas were often located close to noxious industries including: tanneries, wool scouring, soap, candle and brick making, paint manufacturing, furniture manufacturing, gas works, blubber rending, lumber mills, breweries, abattoirs, smelters, fertilizer production, and textile manufacturing (Cushing, 2009; Zierer, 1942). Moreover, steam-driven rail transportation generated smoke, ash, particulates and carbon monoxide, later to be replaced by particulates from diesel engines. These pollutants were readily dispersed to nearby working-class residential areas. By the middle of the twentieth century, inner-city industries included oil refining, asbestos products manufacturing, tyre manufacturing, chemical production, food production, steel refining and production of electrical goods, and impacted on lower-income communities (op. cit.). for light or heavy industrial development. Lead pollution was common, especially in paint manufacturing. Until unleaded petrol was mandated in Australia, highways and other 
transportation corridors also exhibited relatively high levels of lead pollution (Laidlaw and Taylor, 2011; Simpson and Xu, 1994). Furniture production and goods manufacturing generated volatile organic compounds. Manufacturing of goods and chemicals also produced soil and water contamination, typically from chromium, arsenic, boron, copper, among other pollutants. Noxious odours from wastewater treatment plants and sulphur dioxide from power stations also impacted working-class residential areas (Tiller, 1992). The paradox of development at this time is that as heavy industries decentralised into specially designated industrial zones on the outskirts of cities, workers followed - often living nearby in public housing. Suburbs like Kwinana, Western Australia and Elizabeth, South Australia are examples.

Class was a notable environmental border in Australian society at this time. Until the Second World War, it was mostly poor Whites, and to some extent Indigenous groups, who lived in pollution-prone urban areas. The White Australia Policy, which operated until the mid-1960s and was not fully disbanded until the early 1970s, was a significant racial border it meant that ethno-racial discrimination in land use planning was focused on Aboriginal populations (Grimes, 1993). Until the late 1960s, Aboriginal people were subject to spatial segregation policies and curfews, and often lived in remote reserves or 'town camps' near unwanted land uses such as landfill sites (Byrne, 2003; Jackson, 2012; Taylor, 2008). Aboriginal concerns about traditional practices and cultural sites lay outside the 'proper' scope of environmental governance. Following the Second World War though, the Australian immigration literature shows that ethnicity became a new environmental border.

From the 1950s, ethnicity played a growing role in Australian experiences of environmental inequality, as large numbers of low-skilled southern European immigrant groups (Greeks, Italians, Maltese and Yugoslavians) became spatially concentrated in inner 
city areas with dilapidated housing and nearby industries (Burnley, 1971). ${ }^{1}$ Higher-skilled non-Anglo immigrants were also spatially concentrated, but more often near the newer suburban industrial estates (Burnley, 1986, 1999). Both migrant groups worked predominantly in industrial and manufacturing jobs but there is little evidence showing that pollution exposure translated into higher mortality; some even suggest that better diets among southern European immigrants groups may have offset some impacts of environmental pollution (Young, 1987). inequality. Large numbers of Asian (Vietnamese and Chinese) immigrants became spatially concentrated in Australian inner city areas, often close to polluting land uses. From the mid1980s they were joined by Middle-Eastern immigrants from Lebanon and Turkey, who were similarly segregated. Public housing policies meant that these new immigrants were frequently relegated to poorly serviced, higher density locations, oftentimes with obsolete and dilapidated infrastructure (Burnley, 1998). While this new wave of migration coincided with structural economic forces that led to deindustrialization and a downturn in manufacturing, new immigrants were nonetheless exposed to a range of environmental harms such as air pollution from heavy traffic and light industries (e.g. automotive repairs, automotive painting, dry cleaning and metal plating), soil contamination from past industries, exposure to asbestos, and lead paint in older, low quality housing (Murphy, 1993). Yet evidence suggests that some immigrant groups (including Indians, Indonesians, Malaysians, Filipinos and Taiwanese) may have achieved higher social mobility and better environmental quality, thus transcending the ethno-racial border in environmental harm (Burnley, 1998; Zang, 2000).

\footnotetext{
${ }^{1}$ Following the conventions of critical race theory, we take race to refer to purported physiognomic differences between individuals whereas ethnicity refers to purported difference on the basis of religion, culture, language etc. (see Omi, M. \& Winant, H., 1994). Both are social constructs; there is no biological basis to race.
} 
The dynamic nature of Australian cities may partly explain Australian planners’ slow to prominence in the United States during the 1980s, Australian cities were in a state of flux. Locations that were being contested as sites of environmental injustice in the US were being remediated and redeveloped in Australia. Factories were progressively relocated from the urban core to special-purpose industrial estates on the metropolitan periphery, so pollution levels began to decline in the inner city. And with de-industrialisation, which began in the 1970s, came improvement of sorts (Fagan, 1986).

Building Better Cities Program, specially commissioned government redevelopment agencies, supervised pollution remediation and facilitated redevelopment in inner city locales. Former inner city rail yards and industrial areas were assembled into large land holdings for upper income housing (Forster, 2004). Previous residents who included the poor, migrants, Aboriginal people and the working class were displaced in the process (Byrne and Houston, 2005; Searle and Byrne, 2002). Areas developed to serve light manufacturing and service industries in suburban locations came under severe financial stress (Randolph, 2004). Some of these housing estates like Kwinana, Western Australia and Mitchell Park, Adelaide, were subsequently semi-privatised and sold off by state government housing agencies, diluting the spatial concentration of vulnerability (Forster, 2004).

New areas of disadvantage have formed within Australian cities in the twenty-first century - on the suburban periphery. Marginalised and vulnerable residents are now spatially concentrated away from easy access to public transportation. In an era of rising oil vulnerability, they are isolated from essential services and increasingly dependent on the private automobile (Dodson and Sipe, 2007). New forms of environmental inequality have 
emerged too. Researchers have identified various contemporary issues that constitute environmental justice problems in Australian cities, including: access to green-space (Byrne et al., 2010), food deserts (Burns and Inglis, 2007), and obesogenic environments (GilesCorti et al., 2003). Some old problems persist; they too are receiving increasing scrutiny, including: childhood lead poisoning (Laidlaw and Taylor, 2011), exposure to asbestos (Hunter and LaMontagne, 2008), exposure to particulates from coal mining (Higginbotham et al., 2010) and exposure to persistent organic industrial pollutants (Arcioni and Mitchell, 2005; Brown, 2009; James, 2009; Lloyd-Smith and Bell, 2003). A compelling new environmental justice issue in Australian cities is the disproportionate impact of climate 2012).

\section{Conclusions: How should Australian planners respond to environmental (in)justice?}

Environmental justice emerged from the US Civil Rights movement in the 1980s. Although Australian planning systems have a long history of engaging with ideas and ideals of social justice (Fincher and Iveson, 2012), Australian planners have been late to act on environmental justice issues. This is partly because environmental quality management emerged slowly in Australia, and partly because environmental health issues like air pollution only began to be regulated during the mid-twentieth century, mostly outside the jurisdiction of planning (Cushing, 2009; Trumbull, 1972).

Australian planners have made some efforts to engage with environmental protection and management, but have tended to regard environmental health as outside their control (Cleary, 1969). Social justice and environmental protection have thus been treated as separate concerns. While there are Australian environmental justice researchers, they are based in the 
379 disciplines of law, medicine, public health, environmental management, public administration and environmental science - not planning. Moreover, the connections between these disciplines have received far less attention in Australian planning, presenting a significant border to be surmounted.

Environmental justice requires a holistic approach to planning, crossing the 'borders' of class, ethnicity, place, environmental quality, services and amenity - and this is the challenge currently facing Australian planners. Yet there are promising signs that an environmental justice research agenda has begun to emerge in Australia, and Australian planning may slowly be awakening to the importance of this issue (Environmental Defenders Office Victoria, 2012; Gleeson and Memon, 1994; Harris et al., 2009). The task ahead is how to incorporate international environmental justice experiences into Australian planning systems, practice and scholarship, and cross disciplinary silos and boundaries of ignorance and neglect.

An obvious step would be to follow the US lead and enact federal legislation to protect marginalised and vulnerable people from environmental injustices. The Planning Institute of Australia (PIA) could also integrate environmental justice issues into its accreditation process for Australian planning degrees - especially around planning for Indigenous communities. Practitioners and scholars could use PIA as a vehicle to lobby local, state and federal governments to develop environmental justice guidelines, policies and scheme provisions. Identifying examples of best practice would also be a good start. Obviously more work lies ahead if Australian planners are to cross the boundary from passive and/or complicit observers of injustice to becoming advocates for environmental equity. 
Agyeman, J., Bullard, R. D. \& Evans, B., 2003. Just sustainabilities: Development in an unequal world. London: Earthscan Publications.

Arcioni, E. \& Mitchell, G., 2005. Environmental justice in Australia: When the rats became irate. Environmental politics, 14 (3), 363-379.

Arcury, T. A., Quandt, S. A. \& Russell, G. B., 2002. Pesticide safety among farmworkers: Perceived risk and perceived control as factors reflecting environmental justice. Environmental health perspectives, 110 (Suppl 2), 233-240.

Been, V., 1994. Locally undesirable land uses in minority neighborhoods: Disproportionate siting or market dynamics? Yale law journal, 103 (6), 1383-1422.

Boer, J. T., Pastor Jr., M., Sadd, J. L. \& Snyder, L. D., 1997. Is there environmental racism? The demographics of hazardous waste in Los Angeles County. Social science quarterly, 78 (4), 793-810.

Brown, P., 2009. Toxic waste in our midst: Towards an interdisciplinary analysis. Journal of environmental management, 90 (4), 1559-1566.

Bryant, B. I. \& Bryant, B., 1995. Environmental justice: Issues, policies, and solutions. Island Press.

Bullard, R., 1990. Dumping in Dixie: Race, class and environmental quality. Boulder, Co.: Westview Press.

Bullard, R., 1999. Environmental justice challenges at home and abroad. In: N. Low, ed. Global ethics and environment. London: Routledge.

Bullard, R. \& Johnson, G. S., 2000. Environmental justice: Grassroots activism and its impact on public policy decision making. Journal of social issues, 56 (3), 555-578.

Bullard, R. D., 1993. Anatomy of environmental racism and the environmental justice movement. In: R. D. Bullard, ed. Confronting environmental racism: Voices from the grassroots. Boston, Ma.: South End Press.

Bullard, R. D., 1996. Environmental justice: It's more than waste facility siting. Social science quarterly, 77 (3), 493-499.

Burgos, R. \& Pulido, L., 1998. The politics of gender in the Los Angeles bus riders' union/sindicato de pasajeros. Capitalism nature socialism, 9 (3), 75-82.

Burnley, I. H., 1971. Immigrants in Australian cities. The Australian quarterly, 43 (4), 57-69.

Burnley, I. H., 1986. Convergence or occupational and residential segmentation? Immigrants and their Australian-born children in metropolitan Sydney, 1981. Journal of sociology, 22 (1), 65-83.

Burnley, I. H., 1998. Immigrant city, global city? Advantage and disadvantage among communities from Asia in Sydney. The Australian geographer, 29 (1), 49-70.

Burnley, I. H., 1999. Levels of immigrant residential concentration in Sydney and their relationship with disadvantage. Urban studies, 36 (8), 1295-1315.

Burns, C. M. \& Inglis, A. D., 2007. Measuring food access in Melbourne: Access to healthy and fast foods by car, bus and foot in an urban municipality in Melbourne. Health \& place, 13 (4), 877-885. 
Byrne, D. R., 2003. Nervous landscapes race and space in Australia. Journal of social archaeology, 3 (2), 169-193.

Byrne, J. \& Houston, D., 2005. Ghosts in the city: Redevelopment, race and urban memory in East Perth. In: D. Cryle \& J. Hillier, eds., Consent and consensus: Politics, media and governance in twentieth century Australia. Perth: API Network.

Byrne, J., Sipe, N. \& Searle, G., 2010. Green around the gills? The challenge of density for urban greenspace planning in SEQ. Australian planner, 47 (3), 162-177.

Byrne, J. A., 2010. Environmental justice. In: B. Warf, ed. Encyclopedia of geography. Thousand Oaks, CA: SAGE Reference Online, 960-966.

Callewaert, J., 2002. The importance of local history for understanding and addressing environmental injustice. Local environment, 7 (3), 257-267.

Cleary, G. J., 1969. A status report: Air pollution control in Australia. Journal of the air pollution control association, 19 (7), 490-496.

Connor, L., Albrecht, G., Higginbotham, N., Freeman, S. \& Smith, W., 2004. Environmental change and human health in upper hunter communities of New South Wales, Australia. EcoHealth, 1 (Supplement 2), 47-58.

Cushing, N., 2009. Australia's smoke city: Air pollution in Newcastle. Australian economic history review, 49 (1), 19-33.

Cutter, S. L., Holm, D. \& Clark, L., 1996. The role of geographic scale in monitoring environmental justice. Risk analysis, 16 (4), 517-526.

Dodson, J. \& Sipe, N., 2007. Oil vulnerability in the Australian city: Assessing socioeconomic risks from higher urban fuel prices. Urban studies, 44 (1), 37-62.

Environmental Defenders Office Victoria, 2012. Environmental justice project: final report, Melbourne: Environmental Defenders Office Victoria, http://www.edovic.org.au/downloads/files/law_reform/edo_vic_environmental_justic e_report.pdf, accessed 6/2/2013.

Fagan, B., 1986. Industrial restructuring and the metropolitan fringe: Growth and disadvantage in Western Sydney. Australian planner, 24 (1), 11-17.

Fielding, J. \& Burningham, K., 2005. Environmental inequality and flood hazard. Local environment, 10 (4), 379-395.

Fincher, R. \& Iveson, K., 2012. Justice and injustice in the city. Geographical research, doi: 10.1111/j.1745-5871.2011.00742.x

Forster, C., 2004. Australian cities: Continuity and change. 3rd ed. South Melbourne: Oxford University Press.

Gamper-Rabindran, S. \& Timmins, C., 2011. Hazardous waste cleanup, neighborhood gentrification, and environmental justice: Evidence from restricted access census block data. The American economic review, 101 (3), 620-624.

Giles-Corti, B., Macintyre, S., Clarkson, J. P., Pikora, T. \& Donovan, R. J., 2003. Environmental and lifestyle factors associated with overweight and obesity in Perth, Australia. American journal of health promotion, 18 (1), 93-102.

Gleeson, B. \& Coiacetto, E., 2007. Positive planning in Australia: A review of historical and emergent rationales. Urban policy and research, 25 (1), 5-19. 
Gleeson, B. \& Memon, P., 1994. The nimby syndrome and community care facilities: A research agenda for planning. Planning Practice and Research, 9 (2), 105-118.

Gleeson, B. \& Randolph, B., 2002. Social disadvantage and planning in the Sydney context. Urban policy and research, 20 (1), 101-107.

Green, D., Niall, S. and Morrison, J., 2012. Bridging the gap between theory and practice in climate change vulnerability assessments for remote Indigenous communities in northern Australia. Local environment, 17 (3), 295-315.

Grimes, S., 1993. Residential segregation in Australian cities: A literature review. International migration review, 103-120.

Gross, C., 2007. Community perspectives of wind energy in Australia: The application of a justice and community fairness framework to increase social acceptance. Energy policy, 35 (5), 2727-2736.

Harris, P. J., Harris, E., Thompson, S., Harris-Roxas, B. \& Kemp, L., 2009. Human health and wellbeing in environmental impact assessment in New South Wales, Australia: Auditing health impacts within environmental assessments of major projects. Environmental impact assessment review, 29 (5), 310-318.

Harvey, D., 1996. Justice, nature and the geography of difference. Malden, Ma.: Blackwell Publishers.

Haughton, G., 1999. Environmental justice and the sustainable city. Journal of planning education and research, 18 (3), 233.

Higginbotham, N., Freeman, S., Connor, L. and Albrecht, G., 2010. Environmental injustice and air pollution in coal affected communities, Hunter Valley, Australia. Health \& place, 16, 259-266.

Holifield, R., 2001. Defining environmental justice and environmental racism. Urban geography, 22 (1), 78-90.

Hunter, C. \& Lamontagne, A. D., 2008. Investigating ‘community’through a history of responses to asbestos-related disease in an Australian industrial region. Social history of medicine, 21 (2), 361-379.

Jackson, S., 2012. A disturbing story - the fiction of rationality in land use planning in Aboriginal Australia. Australian planner, 49 (3), 274-282.

James, P., 2009. The supervision of environmental risk: The case of HCB waste or Botany/Randwick? Journal of environmental management, 90 (4), 1576-1582.

Kevin, D., 1997. Environmental racism and locally undesirable land uses: A critique of environmental justice theories and remedies. Villanova. environmental. law journal, 8121.

Kurtz, H. E., 2007. Environmental justice, citizen participation and Hurricane Katrina. Southeastern geographer, 47 (1), 111-113.

Laidlaw, M. A. S. \& Taylor, M. P., 2011. Potential for childhood lead poisoning in the inner cities of Australia due to exposure to lead in soil dust. Environmental pollution, 159 (1), 1-9.

Lane, M.B. 1997. Aboriginal participation in environmental planning. Australian geographical studies, 35 (3), 308-323. 
Lewis, M. \& Macleod, R., 1987. A workingman's paradise? Reflections on urban mortality in colonial Australia 1860-1900. Medical history, 31 (4), 387.

Lloyd-Smith, M. E. \& Bell, L., 2003. Toxic disputes and the rise of environmental justice in Australia. International journal of occupational and environmental health, 9 (1), 1423.

Logan, M. I., 1966. Capital city manufacturing in Australia. Economic geography, 42 (2), 139-151.

Low, N., 2000. Global ethics and the environment. London: Routledge.

Low, N. \& Gleeson, B., 1998. Justice, society, and nature: An exploration of political ecology. London: Routledge.

Maantay, J., 2002. Zoning law, health, and environmental justice: What's the connection? The Journal of law, medicine \& ethics, 30 (4), 572-593.

Maantay, J. \& Maroko, A. R., 2009. Mapping urban risk: Flood hazards, race, \& environmental justice in New York. Applied geography, 29 (1), 111-124.

Martin, G., 2005. You can't be neutral on a moving bus: Critical pedagogy as community praxis. Journal for critical education policy studies, 3 (2).

Mennis, J. L., 2005. The distribution and enforcement of air polluting facilities in New Jersey. The professional geographer, 57 (3), 411-422.

Moran, A.F. 2004. The practice of participatory planning at Mapoon Aboriginal Settlement: towards community control, ownership and autonomy. Australian geographical studies, 43 (3), 339-355.

Murphy, P. A., 1993. Immigration and the management of Australian cities: The case of Sydney. Urban studies, 30 (9), 1501-1519.

National Academy of Public Administration, 2003. Addressing community concerns: How environmental justice relates to land use planning and zoning. Washington, DC: National Academy of Public Administration, 1-220.

Neelawala, P., Wilson, C. and Athukorala, W. 2012. The impact of mining and smelting activities on property values: a study of Mount Isa city, Queensland, Australia. Agricultural and resource economics, 57, 60-78.

Omi, M. \& Winant, H., 1994. Racial formation in the United States: From the 1960s to the 1990s. New York: Routledge.

Pastor Jr., M., Sadd, J. L. \& Hipp, J., 2001. Which came first? Toxic facilities, minority move-in, and environmental justice. Journal of urban affairs, 23 (1), 1-21.

Perfecto, I., 1993. Pesticide exposure of farm workers and the international connection. In: B. Bryant \& P. Mohai, eds., Race and the incidence of environmental hazards: A time for discourse. Ann Arbor: University of Michigan Press.

Powell, D. L. \& Stewart, V., 2001. Children: The unwitting target of environmental injustices. Pediatric clinics of North America, 48 (5), 1291-1305.

Pulido, L., 1996. A critical review of the methodology of environmental racism research. Antipode, 28 (2), 142-159. 
Pulido, L., 2000. Rethinking environmental racism: White privilege and urban development in Southern California. Annals of the association of American geographers, 90 (1), 12-40.

Pulido, L., Sidawi, S. \& Vos, R., 1996. An archaeology of environmental racism in Los Angeles. Urban geography, 17 (5), 419-439.

Randolph, B., 2004. The changing Australian city: New patterns, new policies and new research needs. Urban policy and research, 22 (4), 481-493.

Richardson, E. A., Shortt, N. K. \& Mitchell, R. J., 2010. The mechanism behind environmental inequality in Scotland: Which came first, the deprivation or the landfill? Environment and planning A, 42 (1), 223-240.

Rose-Johnson, B., ed. 1994. Who pays the price? The sociocultural context of the environmental crisis. Washington, D.C.: Island Press.

Rydin, Y. \& Pennington, M., 2000. Public participation and local environmental planning: The collective action problem and the potential of social capital. Local environment, 5 (2), 153-169.

Sandercock, L., 1998. Towards cosmopolis: Planning for multicultural cities. Chichester: John Wiley.

Schlosberg, D., 1999. Networks and mobile arrangements: Organisational innovation in the US environmental justice movement. Environmental politics, 8 (1), 122-148.

Searle, G. \& Byrne, J., 2002. Selective memories, sanitised futures: Constructing memories of future place in Sydney. Urban policy and research, 20 (1), 7-25.

Shapiro, M. D., 2005. Equity and information: Information regulation, environmental justice, and risks from toxic chemicals. Journal of policy analysis and management, 24 (2), 373-398.

Simpson, R., Williams, G., Petroeschevsky, A., Best, T., Morgan, G., Denison, L., Hinwood, A., Neville, G. \& Neller, A., 2007. The short-term effects of air pollution on daily mortality in four Australian cities. Australian and New Zealand journal of public health, 29 (3), 205-212.

Simpson, R. W. \& Xu, H., 1994. Atmospheric lead pollution in an urban area-Brisbane, Australia. Atmospheric environment, 28 (19), 3073-3082.

Steele, W., MacCallum, D., Byrne, J. \& Houston, D., 2012. Planning the climate-just city. International planning studies, 17 (1), 67-83.

Sturm, R. \& Cohen, D. A., 2009. Zoning for health? The year-old ban on new fast-food restaurants in South LA. Health affairs, 28 (6), w1088-w1097.

Tan, P-L., Bowmer, K.H. and Baldwin, C., 2012. Continued challenges in the policy and legal framework for collaborative water planning. Journal of hydrology, 474, 84-91.

Taylor, A., 2008. 'The sun always shines in Perth': A post-colonial geography of identity, memory and place. Australian geographical studies, 38 (1), 27-35.

Tiller, K. G., 1992. Urban soil contamination in Australia. Soil research, 30 (6), 937-957.

Troy, P., 2000. The vulnerability of the city. Australian planner, 37 (3), 141-146.

Trumbull, T. A., 1972. Australian air pollution control. Natural resources law., 5477. 
United Church of Christ Commission for Racial Justice, 1987. Toxic waste and race in the United States. New York: United Church of Christ Commission for Racial Justice.

United States General Accounting Office, 1983. Siting of hazardous waste landfills and their correlation with racial and economic status of surrounding communities. Washington D.C.: United States Government Printing Office.

Walker, G., 2009. Beyond distribution and proximity: Exploring the multiple spatialities of environmental justice. Antipode, 41 (4), 614-636.

Wang, X. Y., Hu, W. \& Tong, S., 2009. Long-term exposure to gaseous air pollutants and cardio-respiratory mortality in Brisbane, Australia. Geospatial health, 3 (2), 257-263.

Williams, R. W., 1999. Environmental injustice in America and its politics of scale. Political geography, 18 (1), 49-73.

Wilson, S., Hutson, M. \& Mujahid, M., 2008. How planning and zoning contribute to inequitable development, neighborhood health, and environmental injustice. Environmental justice, 1 (4), 211-216.

Young, C. M., 1987. Migration and mortality: The experience of birthplace groups in Australia. International migration review, 531-554.

Zang, X., 2000. Ecological succession and Asian immigrants in Australia. International migration, 38 (1), 109-125.

Zierer, C. M., 1942. Land use differentiation in Sydney, Australia. Annals of the association of American geographers, 32 (3), 255-308. 